\title{
Clinical Approach to Patients with Chronic Obstructive Pulmonary Disease and Cardiovascular Disease
}

\author{
Stephen I. Rennard \\ University of Nebraska Medical Center, Omaha, Nebraska
}

\begin{abstract}
It has long been recognized that reduced lung function is a major risk factor for cardiac death. It has also become clear that cardiac events are the major cause of death for patients with chronic obstructive pulmonary disease (COPD) with all stages of disease. These associations could be from shared risk factors, most notably cigarette smoking. However, there are mechanistic and physiologic relationships that could account for these associations. This raises the possibility that treatment of COPD could benefit cardiac risks. Despite this, the monitoring of lung function in cardiac patients is not routine. Neither is optimization of lung function, although it may greatly benefit exercise training designed to minimize cardiac risks and symptoms. Conversely, many patients with COPD are at greater risk for cardiac disease than may be recognized, because their COPD is often undiagnosed. Recognition of increased risk could impact the aggressiveness with which other risk factors, hypertension, and hypercholesterolemia are managed. Finally, the interactions between cardiac and pulmonary disease have important implications for the development of novel therapies. It is plausible that treatment of pulmonary inflammation characteristic of COPD will alter cardiac risk. Such an approach would offer a novel approach for the development of treatments for these common conditions.
\end{abstract}

Keywords: cardiovascular disease; chronic obstructive pulmonary disease; comorbidity; diagnosis; therapy

\section{THE CLINICAL INFORMATION-BASE PROBLEM}

Clinical understanding of the patient with chronic obstructive pulmonary disease (COPD) derives from many sources. Observations made by the astute clinician caring for individual patients are often regarded with the lowest level of authority, sometimes being called expert opinion $(1,2)$ and sometimes disparaged as anecdotal. Despite the increasing recognition that the grading systems used have limitations (1), the highest level of regard, particularly for therapeutic recommendations, comes from wellcontrolled, randomized clinical trials (2). Most often, these are conducted for the purpose of evaluating specific treatments. The rigors of such studies often require well-defined patient populations. To avoid confusion, patients with severe or unstable comorbidities are routinely excluded. The consequence of this is that the most highly regarded clinical information often pertains only to a small subset of the patient population. In the EUROSCOP trial (European Respiratory Society Study on Chronic Obstructive Pulmonary Disease) evaluating inhaled corticosteroids in COPD, for example, more than 25 subjects were

(Received in original form October 28, 2004; accepted in final form January 6, 2005) Supported by the Larson Endowment, University of Nebraska Medical Center, Omaha, Nebraska, and AstraZeneca, Lund, Sweden.

Correspondence and requests for reprints should be addressed to Stephen I. Rennard, M.D., Department of Internal Medicine, University of Nebraska Medical Center, 985885 Nebraska Medical Center, Omaha, NE 68198-5885. E-mail: srennard@unmc.edu

Proc Am Thorac Soc Vol 2. pp 94-100, 2005

DOI: $10.1513 /$ pats.200410-051SF

Internet address: www.atsjournals.org screened for each that completed the trial $(3,4)$. This situation is not rare. It is common for large clinical trials to screen many patients of whom only a fraction are included. Many of these may subsequently drop out, further limiting the population base on which important clinical recommendations are commonly made.

\section{COMORBIDITIES}

Among patients with COPD, comorbidities are extremely common for a number of reasons. First, COPD is a disease that increases in importance with age $(5,6)$. Because most chronic disorders of adults also increase with age, statistically, comorbidities will be relatively common among patients with severe COPD. In addition, the major risk factor for the development of COPD is cigarette smoking $(5,6)$. Smoking is also a major risk factor for a large number of other illnesses, including cardiovascular disease (Table 1) (7). As a result of sharing common risk factors, patients with COPD are at further increased risk to suffer these comorbidities.

There may be additional mechanisms in operation. Epidemiologic studies evaluating the risk of heart disease have consistently shown an increased risk among patients with COPD $(8,9)$. This is true even when the data are "corrected" for smoking. There are several mechanisms that may account for this association (Figure 1). First, the lung disease may serve as a "marker" for the cardiac disease. That is, individuals who smoke and are susceptible to the injury caused by smoking may suffer both lung disease and heart disease. Alternatively, it is possible that the lung disease could contribute to the development of cardiac disease, or vice versa. Several lines of evidence suggest that inflammation can contribute to the development of atherosclerosis (10). Increases in C-reactive protein, for example, represent a major risk factor for cardiovascular disease $(11,12)$. In this context, COPD is also an inflammatory disease (13) and increases in C-reactive protein are present in patients with COPD $(14,15)$.

Acute inflammation in the lung, moreover, may put the heart at risk. In this context, periods of increased particulate air pollution are associated with increased mortality, much of which is from cardiac mortality $(16,17)$. Although a number of mechanisms could explain how particulate air pollution could lead to heart disease, induction of inflammation in the lung could do so by at least two mechanisms: first, inflammation in the lung could lead to autonomic instability and predispose to arrhythmias (18); and second, the production of inflammatory cytokines in the lung-for example, interleukin 6-could lead to the hypercoagulable state predisposing to thrombosis $(19,20)$. Finally, inflammation in the lungs, through the release of circulating cytokines such as granulocyte-macrophage colony-stimulating factor, could lead to increased circulating leukocyte numbers and/or activation, which could predispose to an inflammatory rupture of atheromatous plaques (21-23). Although considerable research will be required to determine the mechanisms that account for the association between COPD and heart disease, it seems likely that many patients will suffer from both conditions as a result of shared pathophysiologic mechanisms. 
TABLE 1. DISEASES ASSOCIATED WITH CIGARETTE SMOKING

\begin{tabular}{|c|c|}
\hline $\begin{array}{l}\text { Cardiovascular } \\
\text { Atherosclerotic vascular } \\
\text { disease }\end{array}$ & $\begin{array}{l}\text { Dermatologic disease } \\
\text { Skin wrinkling } \\
\text { Psoriasis }\end{array}$ \\
\hline disease & Psoriasis \\
\hline Coronary artery disease & Reproductive disease \\
\hline Carotid vascular disease & Ovarian failure \\
\hline Abdominal aortic aneurysm & Reduced fertility (women) \\
\hline Mesenteric, renal, iliac & Pregnancy-related \\
\hline Peripheral vascular disease & Preeclampsia (reduced risk) \\
\hline Thromboangiitis obliterans (Berger's) & Prematurity \\
\hline Deep venous thrombosis & Premature rupture of membranes \\
\hline Pulmonary embolus & Placenta previa \\
\hline Cardiac disease & Placental abruption \\
\hline Angina pectoris & Spontaneous abortion \\
\hline Coronary artery spasm & Decreased sperm quality \\
\hline Arrythmia & Fetal effects \\
\hline Malignancy & Low birth weight \\
\hline Respiratory tract & Impaired lung growth \\
\hline Lung cancer & Sudden infant death syndrome \\
\hline Squamous cell & Febrile seizures \\
\hline Adenocarcinoma & Reduced intelligence \\
\hline Large cell & Behavioral disorders \\
\hline Small cell & Atopic disease/asthma \\
\hline Laryngeal cancer & Effects on children of parental smoking \\
\hline Oral cavity and pharyngeal cancer & Asthma \\
\hline Other tissues & Rhinitis \\
\hline Esophagus & Otitis \\
\hline Pancreas & Pneumonia \\
\hline Bladder & Increased risk to smoke \\
\hline Uterine cervix & Rheumatologic and bone disease \\
\hline Endometrial & Osteoporosis \\
\hline Breast & Post menopausal \\
\hline Kidney & Hip fractures \\
\hline Anus & Rheumatoid arthritis \\
\hline Penis & Psychiatric \\
\hline Stomach & Depression \\
\hline Colorectal & Schizophrenia \\
\hline Liver & Oral disease \\
\hline Leukemia (acute myeloid leukaemia) & Periodontal disease \\
\hline Lung disease & Caries \\
\hline Chronic obstructive pulmonary disease & Loss of taste \\
\hline Emphysema & Loss of olfaction \\
\hline Chronic bronchitis & Infectious disease \\
\hline Asthma & Tuberculosis \\
\hline Other lung diseases & Pneumococcal infection \\
\hline Idiopathic pulmonary fibrosis & Meningococcal infection \\
\hline Histiocytosis X & Endocrine disease \\
\hline Respiratory bronchiolitis & Altered hormonal secretion \\
\hline Goodpasture's syndrome & Grave's disease \\
\hline Sleep apnea & Antidiuresis \\
\hline Pneumothorax & Goiter \\
\hline Pneumonia & Renal disease \\
\hline Gastrointestinal disease & Glomerulonephritis \\
\hline Peptic ulcer disease & Benign prostatic hypertrophy \\
\hline Associated with Helicobacter & Eye disease \\
\hline pylori & Nuclear cataract \\
\hline Gastroesophageal reflux & Nuclear opacity \\
\hline Chronic pancreatitis & Macular degeneration \\
\hline Crohn's disease & Grave's disease ophthalmopathy \\
\hline Colonic adenomas & Erectile dysfunction \\
\hline
\end{tabular}

Modified from Reference 79. Items listed have been suggested to be associated with smoking. Those for which the Surgeon General's report found sufficient evidence to suggest a causal relationship are indicated in bold type (7).

\section{FUNCTIONAL INTERDEPENDENCE}

The heart and lungs are, obviously, integrated physiologically. Patients with COPD likely stress their hearts in a number of important ways both at rest and with exercise (Figure 2). First, the work of breathing is increased in patients with COPD. This is true at rest and becomes increasingly so as the respiratory rate increases. Total oxygen uptake can more than double when a patient with COPD voluntarily hyperventilates and increases ventilation only twofold. In contrast, a normal individual can voluntarily increase ventilation eight- to tenfold with only a $25 \%$ increase in total oxygen consumption (24). This increased work of breathing, particularly with the hyperventilation of exercise, where work of breathing may represent $50 \%$ of total oxygen consumption (25), may constitute a very real problem for an individual with compromised cardiac function.

To make matters worse, cardiac function can be compromised by the presence of COPD. Pulmonary hypertension can develop 


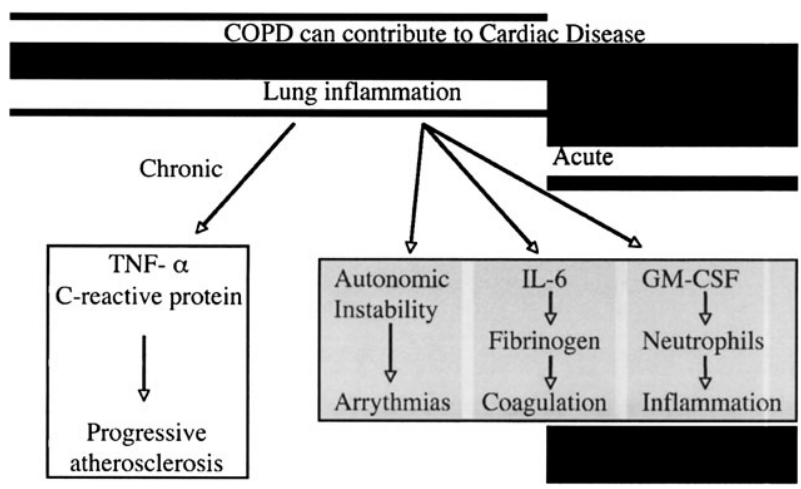

Figure 1. Chronic obstructive pulmonary disease (COPD) can contribute to cardiac disease by a variety of mechanisms. Chronic inflammation in the lung may lead to circulating cytokines and mediators (e.g. tumor necrosis factor $\alpha[\mathrm{TNF}-\alpha]$ or C-reactive protein), which may accelerate the development of atherosclerosis. Acute inflammation may predispose to the development of acute cardiac events by a number of mechanisms (see text for details). IL-6 = interleukin 6; GM-CSF = granulocytemacrophage colony-stimulating factor.

in patients with COPD either as a result of loss of alveolar capillary bed or as a consequence of chronic alveolar hypoxia with secondary vasoconstriction. Cor pulmonale, which is characterized by hypertrophy, dilatation, and finally failure of the right ventricle, classically develops as a result of chronic pulmonary hypertension (26). The routine use of long-term oxygen therapy for patients with hypoxic COPD improves survival $(27,28)$ and likely has markedly reduced the prevalence of cor pulmonale, probably by prevention because reversal of pulmonary hypertension, when present, is only modest $(29,30)$. Fluid and electrolyte balance is abnormal in patients with COPD with cor pulmonale caused by abnormal production of naturietic hormones from both hypoxia and distension of pulmonary vessels and the right side of the heart (26). Even in the absence of pulmonary hypertension, however, fluid balance in COPD may still be abnormal. The factors that contribute to abnormal fluid and electrolyte balance in COPD are not completely defined, but systemic abnormalities likely play a role (31).

Because the lung normally accommodates increasing cardiac output by recruiting additional vessels, exercise, with the associated increased cardiac output, may further exacerbate pulmonary hypertension in patients with COPD where the pulmonary capillary bed is compromised (32). In addition, with exercise, respiratory rate increases. As a result, there is insufficient time for the lung to fully empty, and the lung becomes progressively and dynamically hyperinflated (33). This is a major cause of dyspnea after exercise and will further increase work of breathing. In addition, attendant with this hyperinflation is an increase in intrathoracic pressure that can restrict venous return and compromise cardiac output (25). Clinically, it is often difficult to distinguish between cardiac and pulmonary disease as a cause for dyspnea. Often, detailed functional exercise testing is required to help determine a physiologic basis for symptoms (34). Acute exacerbations of COPD and chronic heart failure can also be difficult to distinguish clinically. The assessment of brain naturietic peptide (BNP) may prove useful in this regard (35).

\section{CLINICAL GUIDELINES}

Recognizing that heart disease and lung disease are frequently concurrent and may be interconnected pathophysiologically, what recommendations have been made to guide the clinician?
Effects of COPD on Cardiac Function

\begin{tabular}{|c|c|c|c|}
\hline Rest & Lung hyperinflation & Exercise & $\begin{array}{c}\text { Cardiac } \\
\text { consequence }\end{array}$ \\
\hline$\uparrow$ & Work of breathing & $\uparrow \uparrow \uparrow \uparrow$ & $\begin{array}{l}\text { Need to deliver } \\
\text { increased cardiac } \\
\text { output }\end{array}$ \\
\hline Normal $/ \uparrow$ & Intrathoracic pressure & $\uparrow \uparrow \uparrow \uparrow$ & $\begin{array}{l}\text { Decreased venous } \\
\text { return (cardiac } \\
\text { output) }\end{array}$ \\
\hline Normal $/ \uparrow$ & Pulmonary hypertension & $\uparrow \uparrow \uparrow \uparrow$ & $\begin{array}{l}\text { Increased cardiac } \\
\text { strain: limited } \\
\text { increase cardiac } \\
\text { output }\end{array}$ \\
\hline
\end{tabular}

Figure 2. The abnormally functioning lung in COPD can compromise cardiac function in several ways. At rest, COPD has relatively mild effects, although work of breathing, hyperinflation, intrathoracic pressure, and pulmonary vascular pressures may be elevated. These are markedly worsened by exercise. These dysfunctions increase the demands on the heart to deliver oxygen to tissues (the muscles of respiration) while limiting the ability to increase cardiac output. Interventions could improve lung function in several ways: for example, reduction in dynamic hyperinflation, reduction in intrathoracic pressure, reduction in pulmonary vascular pressure, and reduction, which, by affecting the lung, could secondarily improve cardiac performance. In addition, reducing the work required for breathing could result in reduced demand on the heart and an apparent improvement in cardiac performance (see text for details).

There is, unfortunately, a striking lack of specific recommendations for the management of patients with concurrent COPD and cardiac disease. This is not because of a failure to recognize the association. Rather, it reflects the lack of evidence on the specific management of patients with the simultaneous presence of both problems. The most recent guidelines for the management of the patients with COPD are those provided by the Global Initiative for Chronic Obstructive Lung Disease (GOLD) (13), which have been recently expanded by the American Thoracic Society/European Respiratory Society (13). Although these two sets of guidelines recognize that cardiac disease is often present as a comorbidity, no specific recommendations for dealing with the practical issues that a clinician is likely to encounter are given. This results directly from the tension to keep the guidelines "evidence-based" and that the majority of clinical "evidence" comes from clinical trials that selectively exclude patients with significant comorbidities.

The American College of Cardiology/American Heart Association guidelines for the evaluation of management of chronic heart failure in the adult (36) also make note of the common association of heart failure and pulmonary disease. Exercise testing with blood gas measurements, possibly with right heart catheterization, is suggested as a means to help determine which conditions are most important. Therapeutically, specific recommendations are given regarding angiotensin-converting enzyme inhibitors and $\beta$-blockers. Because both metoprolol and bisoprolol lose $\beta-1$ selectivity when used in doses sufficient to improve survival in patients with heart failure, these agents are not indicated for patients with asthma. On the other hand, they can be used effectively in patients with COPD who do not have acute bronchospasm $(37,38)$, and this is included in the guidelines.

Heart failure is only one form of heart disease, and guidelines have also been prepared for conditions associated with increased 
risk of cardiovascular disease, including the following: National Institutes of Health Guidelines on Evaluation and Treatment of Overweight and Obesity in Adults (39); Treatment of High Blood Cholesterol in Adults (40) and on the Prevention, Detection, Evaluation, and Treatment of High Blood Pressure (41); the U.S. Public Health Service Clinical Practice Guideline: Treating Tobacco Use and Dependency (42); and the American Heart Association Guidelines for Primary Prevention of Cardiovascular Disease and Stroke (43). COPD is not addressed in the obesity or hypertension guidelines and is not included in the list of cardiac risk factors in the cardiovascular disease guidelines. There is, therefore, a paucity of recommendations to guide clinicians in the specific care of patients with COPD who suffer from obesity, hypercholesterolemia, hypertension, or other risk factors. The best advice would be to treat patients with COPD in the same way they would other patients with these disorders. However, this may not always be correct.

\section{OBESITY}

Although obesity is clearly a risk factor for mortality from cardiac disease, the relationship between weight and COPD risk may be more complex. For patients with COPD, mortality is increased as weight decreases. Two studies demonstrated this across all weight groups and mortality was lowest for patients who were obese $(44,45)$. These results differ slightly from the follow-up of the first National Health and Nutrition Examination Survey (NHANES). Although in NHANES, mortality was highest among those who were underweight, mortality also began to rise again among individuals who were obese (46). Starvation, moreover, is associated with the development of emphysema, both in animal models $(47,48)$ and in humans $(49)$. Thus, whether the recommendation to lose weight should be given to overweight and obese patients with COPD as it would to such patients without COPD is unclear. It is reasonable to assume that obesity can compromise the mechanical efficiency of the chest and can increase the work required for daily activities. Additional data on the effects of weight loss in obese patients with COPD, therefore, are needed.

The mechanisms that account for the association between loss of weight and increased mortality among patients with COPD have been the subject of much study. Weight loss in patients with COPD has been attributed to the effect of circulating cytokines. In particular, the cytokine tumor necrosis factor- $\alpha$ $(\mathrm{TNF}-\alpha)$, which has been related to cachexia in a number of conditions, has been suggested to play a role. $\mathrm{TNF}-\alpha$ is produced in the lung in COPD (50), and increased amounts are reported in bronchoalveolar lavage fluid (51) and induced sputum (52). Although controversial $(53,54)$, several studies have demonstrated increased levels of TNF- $\alpha$ in the circulation in patients with COPD who have lost weight (55-59). In addition, underweight patients with COPD have peripheral blood monocytes that appear to produce increased amounts of TNF in response to a standard stimulus (60). Finally, polymorphisms in the TNF- $\alpha$ gene that may account for increased TNF- $\alpha$ production have been described in a population in Taiwan (61), although this has not been repeated in other studies (62-64). TNF- $\alpha$ is a potent inducer of apoptosis in many cell types. Whether it contributes to the skeletal muscle abnormalities present in COPD (65) is unclear, but a relationship between loss of muscle mass and circulating TNF- $\alpha$ has been reported (57). Whether cytokines other than TNF- $\alpha$ play a similar role is largely unexplored.

Patients with COPD likely lose weight for a variety of reasons $(66,67)$. In addition to the effects of circulating cytokines, caloric needs may be increased because of the increased work of breathing and inefficient exercise performance. Depression or other factors that compromise nutrition could also play a role. How these factors may interact with cardiac disease and whether they are relevant to the patient with COPD who is overweight remains to be determined. However, even overweight patients with COPD may have a decrease in fat-free mass (66). This may account for decreased exercise performance. Because decreased muscle mass is a major driver of decreased performance in patients with COPD (68), simple recommendations to lose weight may not be correct for overweight patients with COPD.

\section{REHABILITATION AND EXERCISE}

Both patients with COPD and patients with cardiac disease can benefit from exercise training. Rehabilitation programs can substantially reduce cardiac risk and should, therefore, be part of the management program of all patients who are at hazard (69). Rehabilitation can, moreover, dramatically improve quality of life among patients with COPD $(70,71)$.

How best to implement the rehabilitation program among patients with concurrent cardiac and heart disease is not fully determined. In this regard, the intensity of the exercise training is a key factor in determining the training benefit (72). Even modest degrees of COPD, however, can compromise training. In this regard, increasing respiratory rate is associated with dynamic hyperinflation (33). This likely leads to dyspnea and may, as noted previously, compromise cardiac output (25). As a result, the benefits of exercise training may be difficult to achieve in the presence of even mild COPD. Additional studies of exercise training and rehabilitation among patients with concurrent cardiac disease and COPD are needed to determine whether interventions for COPD that may be otherwise asymptomatic may improve training benefits and result in cardiac benefits.

\section{BRONCHODILATORS}

Bronchodilators can result in a reduction in dynamic hyperinflation $(73,74)$. This benefit may accrue even when there are modest effects on airflow measured at rest (75). Whether bronchodilators should be used routinely during exercise training, particularly among patients with mild COPD, remains undetermined. Such an intervention, however, by permitting more effective training may have a dramatic impact on the ability of exercise training to reduce cardiac risk.

\section{OXYGEN}

A similar potential benefit has been demonstrated by Casaburi for oxygen (73). Oxygen administration reduces respiratory rate even among individuals who are normoxic both at rest and with exercise (76). The reduction in respiratory rate may be caused by an effect on the carotid body and may be independent of improved oxygen delivery. By whatever mechanism, patients with COPD who are normoxic can exercise to higher levels of intensity with supplemental oxygen, presumably because of reduced dynamic hyperinflation. The improved exercise training may be of benefit, particularly for those patients with concurrent heart disease. Such an intervention, however, has not been tested with sufficient rigor to warrant inclusion in any practice guideline.

\section{SMOKING CESSATION}

Smoking cessation is the most important health intervention for all smokers (77). Cessation early in the course of the disease can slow the progression of COPD (78). Cessation is associated with a rapid reduction in risk of acute cardiac events and, over longer time frames, with improvement in atherosclerotic vascular disease (77). Smoking cessation, in addition, has numerous other 
TABLE 2. CARDIAC RISK FACTORS TO CONSIDER IN PATIENTS WITH CHRONIC OBSTRUCTIVE PULMONARY DISEASE

\author{
Hypertension \\ Diabetes \\ Cholesterol \\ Renal compromise (glomerular filtration rate $<60 \mathrm{ml} /$ minute) \\ Microalbuminemia \\ Obesity \\ Physical inactivity \\ Family history \\ Suggested lung assessment in patients at risk for cardiac disease \\ FEV \\ FVC or FEV \\ If any abnormalities present, consider \\ Post-bronchodilator FEV \\ Lung volumes \\ $\mathrm{DL}_{\mathrm{CO}}$ \\ Exercise challenge (with and without bronchodilator*)
}

Definition of abbreviation: $\mathrm{DL}_{c 0}=$ carbon monoxide diffusion coefficient

* It is possible that reduced tachypnea will lead to increased exercise tolerance. The clinical implications of this are uncertain. See text for details.

health benefits (77). Currently recommended smoking cessation treatments have been evaluated in patients with both cardiac disease (79) and COPD, and the available data support their efficacy in these populations (42).

\section{NOVEL APPROACHES TO THERAPY}

There are several reasons to consider novel approaches to the development of cardiac and pulmonary diseases by evaluating them together. The physiologic interdependence of the organ systems makes it possible that treatment of otherwise mild cardiac disease may benefit respiratory function in patients with COPD and vice versa. This may result in novel endpoints in clinical trials. It is also possible that cardiac and respiratory disease can share mechanisms. For example, antiinflammatory therapy treatment of COPD may benefit cardiovascular disease, and statin therapy for heart disease could have antiinflammatory effects on lung disease. Specific information on the management of patients with concurrent cardiac and pulmonary disease would, at a minimum, be helpful to the clinician.

\section{THE CLINICIAN'S ISSUES}

What is clear is that the clinician faced with a patient who has either cardiovascular disease or COPD is facing a patient who is at risk for both conditions. All patients with COPD, therefore, should be carefully evaluated for cardiac risk factors (Table 2). Those risk factors should be treated appropriately according to current guidelines. Similarly, patients with cardiovascular disease should be routinely assessed for the presence of COPD. The current GOLD guidelines suggest that any airflow limitation below $80 \%$ predicted is an indication for consideration of bronchodilators (13), particularly with exercise. Because routine exercise training is indicated even for the "asymptomatic" patient with cardiac and lung disease, it is reasonable to consider bronchodilator therapy, and perhaps oxygen, as needed to facilitate performance.

What is also clear is that a large number of crucially important questions remain unanswered. To what degree shared pathophysiologic mechanisms can be addressed remains unanswered. Would treatment of lung inflammation, for example, decrease risk of acute cardiac events? Would treatment of lung inflammation decrease risk for progression of atherosclerosis? Would treatment of lung inflammation decrease risk for thrombotic events? Finally, it is unclear whether treatment of heart disease can affect the progression of lung disease. Recent studies by Kasahara and colleagues (75) have clearly demonstrated that abnormalities in the pulmonary vasculature consequent to impaired signaling through vascular endothelial growth factor can lead to the development of emphysema (74). Similar abnormalities seem to be present in patients with COPD (75). Whether treatment of cardiac disease designed to correct vascular physiology will benefit lung disease is unclear. Finally, although the lung may be a source of inflammatory cytokines, it may also be a target. Systemic administration of TNF- $\alpha$, for example, has been reported to lead to the development of emphysema in animal models (76). Statin drugs are routinely used to lower cholesterol, but these agents may have clinically relevant antiinflammatory effects $(77,78)$. The recognition that atherosclerosis is an inflammatory disease will likely lead to treatment of heart disease with these or other antiinflammatory modalities. The implications of such therapy for COPD are unknown, but such intervention could potentially affect the progression of lung disease. The resolution of these questions holds great promise to improve the care of the large group of patients who suffer from both heart and lung disease.

Conflict of Interest Statement: S.I.R. has participated as a speaker in scientific meetings and courses under the sponsorship of AstraZeneca, GlaxoSmithKline, and Pfizer, and has consulted with several pharmaceutical companies with relevance to the topics noted in the present article (Almiral, Altana Amersham, Array Biopharma, AstraZeneca, Aventis, Boehringer Ingelheim, Critical Therapeutics, GlaxoSmithKline, Globomax, Intermune, Merck, Novartis, Ono, Otsuka, Roche, Sanofi, Scios, Wyeth) and serves on advisory boards for Altana and Inspire and has been sponsored by GlaxoSmithKline for several clinical trials and has received laboratory support and has also conducted clinical trials for Roche, Pfizer, Sanofi, and Novartis, and has conducted both clinical trials and basic studies under the sponsorship of Centocor and has conducted basic studies under the sponsorship of AstraZeneca, and a patent is pending on the use of PDE4 inhibitors in repair, and is a coinventor of the patent owned by the University of Nebraska Medical Center.

\section{References}

1. Harbour R, Miller J. A new system for grading recommendations in evidence based guidelines. BMJ 2001;323:334-336.

2. Hadorn DC, Baker D, Hodges JS, Hicks N. Rating the quality of evidence for clinical practice guidelines. J Clin Epidemiol 1996;49:749-754.

3. Lofdahl CG, Postma DS, Laitinen LA, Ohlsson SV, Pauwels RA, Pride NB. The European Respiratory Society Study on Chronic Obstructive Pulmonary Disease (EUROSCOP): recruitment methods and strategies. Respir Med 1998;92:467-472.

4. Pauwels RA, Lofdahl CG, Laitinen LA, Schouten JP, Postma DS, Pride NB, Ohlsson SV. Long-term treatment with inhaled budesonide in persons with mild chronic obstructive pulmonary disease who continue smoking. N Engl J Med 1999;340:1948-1953.

5. Fletcher C, Peto R, Tinker C, Speizer FE. The natural history of chronic bronchitis and emphysema. New York: Oxford University Press; 1976.

6. Mannino DM, Gagnon RC, Petty TL, Lydick E. Obstructive lung disease and low lung function in adults in the United States: data from the National Health and Nutrition Examination Survey, 1988-1994. Arch Intern Med 2000;160:1683-1689.

7. U.S. Surgeon General. The health consequences of smoking: a report of the Surgeon General. Washington, DC: Department of Health and Human Services, Centers for Disease Control and Prevention, National Center for Chronic Disease Prevention and Health Promotion, Office on Smoking and Health; 2004.

8. Ashley F, Kannel WB, Sorlie PD, Masson R. Pulmonary function: relation to aging, cigarette habit, and mortality. Ann Intern Med 1975;82:739745.

9. Dankner R, Goldbourt U, Boyko V, Reicher-Reiss H. Predictors of cardiac and noncardiac mortality among 14,697 patients with coronary heart disease. Am J Cardiol 2003;91:121-127.

10. Willerson JT, Ridker PM. Inflammation as a cardiovascular risk factor Circulation 2004;109:II2-II10.

11. Libby P, Ridker PM. Inflammation and atherosclerosis: role of C-reactive protein in risk assessment. Am J Med 2004;116(Suppl 6A): 9S-16S.

12. Yeh ETH. CRP as a mediator of disease. Circulation 2004;109:II11-II14. 
13. Global Initiative for Chronic Obstructive Lung Disease. Global strategy for the diagnosis, management and prevention of chronic obstructive lung disease. NHLBI/WHO workshop report. Bethesda, MD: National Heart, Lung, and Blood Institute; 2001. Update of the management sections, GOLD Web site (www.goldcopd.com). Date updated: July 2003.

14. Sin DD, Man SF. Why are patients with chronic obstructive pulmonary disease at increased risk of cardiovascular diseases? The potential role of systemic inflammation in chronic obstructive pulmonary disease. Circulation 2003;107:1514-1519.

15. Mannino DM, Ford ES, Redd SC. Obstructive and restrictive lung disease and markers of inflammation: data from the Third National Health and Nutrition Examination. Am J Med 2003;114:758-762.

16. Katsouyanni K, Zmirou D, Spix C, Sunyer J, Schouten JP, Ponka A, Anderson HR, Le Moullec Y, Wojtyniak B, Vigotti MA, et al. Shortterm effects of air pollution on health: a European approach using epidemiologic time series data. The APHEA Project. Air Pollution Health Effects-A European Approach. Public Health Rev 1997;25: 7-18 [discussion: 19-28].

17. Samet JM, Dominici F, Curriero FC, Coursac I, Zeger SL. Fine particulate air pollution and mortality in 20 U.S. cities, 1987-1994. N Engl J Med 2000;343:1742-1749.

18. Wellenius GA, Saldiva PH, Batalha JR, Krishna Murthy GG, Coull BA, Verrier RL, Godleski JJ. Electrocardiographic changes during exposure to residual oil fly ash (ROFA) particles in a rat model of myocardial infarction. Toxicol Sci 2002;66:327-335.

19. Wedzicha JA, Seemungal TA, MacCallum PK, Paul EA, Donaldson GC, Bhowmik A, Jeffries DJ, Meade TW. Acute exacerbations of chronic obstructive pulmonary disease are accompanied by elevations of plasma fibrinogen and serum IL-6 levels. Thromb Haemost 2000;84: 210-215.

20. Gong H Jr, Sioutas C, Linn WS. Controlled exposures of healthy and asthmatic volunteers to concentrated ambient particles in metropolitan Los Angeles. Res Rep Health Eff Inst 2003;118:1-36 [discussion: 37-47].

21. van Eeden SF, Tan WC, Suwa T, Mukae H, Terashima T, Fujii T, Qui D, Vincent R, Hogg JC. Cytokines involved in the systemic inflammatory response induced by exposure to particulate matter air pollutants $\left(\mathrm{PM}_{10}\right)$. Am J Respir Crit Care Med 2001;164:826-830.

22. Suwa T, Hogg JC, Quinlan KB, Ohgami A, Vincent R, van Eeden SF. Particulate air pollution induces progression of atherosclerosis. $\mathrm{J} \mathrm{Am}$ Coll Cardiol 2002;39:935-942.

23. Tan WC, Qiu D, Liam BL, Ng TP, Lee SH, van Eeden SF, D'Yachkova $\mathrm{Y}$, Hogg JC. The human bone marrow response to acute air pollution caused by forest fires. Am J Respir Crit Care Med 2000;161:1213-1217.

24. Cherniack RM, Cherniack L, Naimark A. Respiration in health and disease. Philadelphia: W.B. Saunders; 1972. pp. 323-324.

25. Aliverti A, Macklem PT. How and why exercise is impaired in COPD. Respiration (Herrlisheim) 2001;68:229-239.

26. Rappaport E. Cor pulmonale. In: Murray JJ, Nadel JA, Mason RM, Boushey $\mathrm{H}$, editors. Textbook of respiratory medicine. Philadelphia: W.B. Saunders; 2000. pp. 1631-1648.

27. Medical Research Council. Long-term domiciliary oxygen therapy in chronic hypoxic cor pulmonale complicating chronic bronchitis and emphysema. Report of the Medical Research Council Working Party. Lancet 1981;1(8222):681-686.

28. Kvale PA, Cugell DW, Anthonisen NR, Timms RM, Petty TL, Boylen CT. Continuous or nocturnal oxygen therapy in hypoxemic chronic obstructive lung disease. Ann Intern Med 1980;93:391-398.

29. Timms RM, Khaja FU, Williams GW. Hemodynamic response to oxygen therapy in chronic obstructive pulmonary disease. Arch Intern Med 1985;102:29-36.

30. Weitzenblum E, Sautegeau A, Ehrhart M, Mammosser M, Pelletier A. Long-term oxygen therapy can reverse the progression of pulmonary hypertension in patients with chronic obstructive pulmonary disease. Am Rev Respir Dis 1985;131:493-498.

31. de Leeuw PW, Dees A. Fluid homeostasis in chronic obstructive lung disease. Eur Respir J Suppl 2003;46:33s-40s.

32. Burrows B, Kettel LJ, Niden AH, Rabinowitz M, Diener CF. Patterns of cardiovascular dysfunction in chronic obstructive lung disease. $N$ Engl J Med 1972;286:912-918.

33. O'Donnell DE, Revill SM, Webb KA. Webb, Dynamic hyperinflation and exercise intolerance in chronic obstructive pulmonary disease. Am J Respir Crit Care Med 2001;164:770-777.

34. Hunt SA, Baker DW, Chin MH, Cinquergrani MP, Feldman AM, Francis GS, Ganiats TG, Goldstein S, Gregoratos G, Jessup ML. ACC/AHA guidelines for the evaluation and management of chronic heart failure in the adult: a report of the American College of Cardiology/American
Heart Association Task Force on Practice Guidelines. J Am Coll Cardiol 2001;38:2101-2113.

35. Salpeter SR, Ormiston TM, Salpeter EE, Poole PJ, Cates CJ. Cardioselective beta-blockers for chronic obstructive pulmonary disease: a metaanalysis. Respir Med 2003;97:1094-1101.

36. Andrus MR, Holloway KP, Clark DB. Use of beta-blockers in patients with COPD. Ann Pharmacother 2004;38:142-145.

37. National Institutes of Health. Clinical guidelines on the identification, evaluation and treatment of overweight and obesity in adults. 1998. NIH Publication No. 98-4083.

38. National Institutes of Health. Detection, evaluation, and treatment of high blood cholesterol in adults. 2001. NIH Publication No. 01-3670.

39. Chobanian AV, Bakris GL, Black HR, Cushman WC, Green LA, Izzo JL Jr, Jones DW, Materson BJ, Oparil S, Wright JT Jr, et al. Joint National Committee on Prevention, Detection, Evaluation, and Treatment of High Blood Pressure. National Heart, Lung, and Blood Institute; National High Blood Pressure Education Program Coordinating Committee. Seventh report of the Joint National Committee on Prevention, Detection, Evaluation and Treatment of High Blood Pressure. Hypertension 2003;42:1206-1252.

40. Schols AM, Slangen J, Volovics L, Wouters EF. Weight loss is a reversible factor in the prognosis of chronic obstructive pulmonary disease. Am J Respir Crit Care Med 1998;157:1791-1797.

41. Chailleux E, Fauroux B, Binet F, Dautzenberg B, Polu JM. Predictors of survival in patients receiving domiciliary oxygen therapy or mechanical ventilation. Chest 1996;109:741-749.

42. Mannino DM, Buist AS, Petty TL, Enright PL, Redd SC. Lung function and mortality in the United States: data from the First National Health and Nutrition Examination Survey follow up study. Thorax 2003;58: 388-393.

43. Sahebjami H, Wirman JA. Emphysema-like changes in the lungs of starved rats. Am Rev Respir Dis 1981;124:619-624.

44. Massaro GD, Radaeva S, Clerch LB, Massaro D. Lung alveoli: endogenous programmed destruction and regeneration. Am J Physiol Lung Cell Mol Physiol 2002;283:L305-L309.

45. Stein J, Fenigstein H. Anatomie pathologique de la maladie de famine [in French]. In: Apfelbaum E, editor. Maladie de famine. Warsaw, Poland: American Joint Distribution Committee; 1946. pp. 21-27.

46. Jeffery PK. Comparative morphology of the airways in asthma and chronic obstructive pulmonary disease. Am J Respir Crit Care Med 1994; 150:S6-S13.

47. Soler N, Ewig S, Torres A, Filella X, Gonzalez J, Zaubet A. Airway inflammation and bronchial microbial patterns in patients with stable chronic obstructive pulmonary disease. Eur Respir J 1999;14:1015-1022.

48. Keatings VM, Collins PD, Scott DM, Barnes PJ. Differences in interleukin- 8 and tumor necrosis factor- $\alpha$ in induced sputum from patients with chronic obstructive pulmonary disease or asthma. Am J Respir Crit Care Med 1996;153:530-534.

49. Karadag F, Karul AB, Cildag O, Altun C, Gurgey O. Determinants of BMI in patients with COPD. Respirology 2004;9:70-75.

50. Calikoglu M, Sahin G, Unlu A, Ozturk C, Tamer L, Ercan B, Kanik A, Atik U. Leptin and TNF- $\alpha$ levels in patients with chronic obstructive pulmonary disease and their relationship to nutritional parameters. Respiration (Herrlisheim) 2004;71:45-50.

51. Di Francia M, Barbier D, Mege JL, Orehek J. Tumor necrosis factoralpha levels and weight loss in chronic obstructive pulmonary disease. Am J Respir Crit Care Med 1994;150:1453-1455.

52. Yamamoto C, Yoneda T, Yoshikawa M, Fu A, Takenaka I, Kobayashi A, Okamura I, Okamoto Y, Tsukaguchi K, Narita N. The relationship between a decrease in fat mass and serum levels of TNF-alpha in patients with chronic obstructive pulmonary disease. Nihon Kyobu Shikkan Gakkai Zasshi 1997;35:1191-1195.

53. Eid AA, Ionescu AA, Nixon LS, Lewis-Jenkins V, Matthews SB, Griffiths TL, Shale DJ. Inflammatory response and body composition in chronic obstructive pulmonary disease. Am J Respir Crit Care Med 2001;164: 1414-1418.

54. Schols AM, Creutzberg EC, Buurman WA, Campfield LA, Saris WH, Wouters EF. Plasma leptin is related to proinflammatory status and dietary intake in patients with chronic obstructive pulmonary disease. Am J Respir Crit Care Med 1999;160:1220-1226.

55. Takabatake N, Nakamura H, Abe S, Inoue S, Hino T, Saito H, Yuki H, Kato S, Tomoike $\mathrm{H}$. The relationship between chronic hypoxemia and activation of the tumor necrosis factor- $\alpha$ system in patients with chronic obstructive pulmonary disease. Am J Respir Crit Care Med 2000; 161: $1179-1184$

56. Nguyen LT, Bedu M, Caillaud D, Beaufrere B, Beaujon G, Vasson M, Coudert J, Ritz P. Increased resting energy expenditure is related 
to plasma TNF- $\alpha$ concentration in stable COPD patients. Clin Nutr 1999;18:269-274.

57. de Godoy I, Donahoe M, Calhoun WJ, Mancino J, Rogers RM. Elevated TNF- $\alpha$ production by peripheral blood monocytes of weight-losing COPD patients. Am J Respir Crit Care Med 1996;153:633-637.

58. Huang SL, Su CH, Chang SC. Tumor necrosis factor- $\alpha$ gene polymorphism in chronic-bronchitis. Am J Respir Crit Care Med 1997;156:14361439.

59. Higham MA, Pride NB, Alikhan A, Morrell NW. Tumour necrosis factoralpha gene promoter polymorphism in chronic obstructive pulmonary disease. Eur Respir J 2000;15:281-284.

60. Ishii T, Matsuse T, Teramoto S, Matsui H, Miyao M, Hosoi T, Takahashi H, Fukuchi Y, Ouchi Y. Neither IL-1beta, IL-1 receptor antagonist, nor TNF-alpha polymorphisms are associated with susceptibility to COPD. Respir Med 2000;94:847-851.

61. Ferrarotti I, Zorzetto M, Beccaria M, Gile LS, Porta R, Ambrosino N, Pignatti PF, Cerveri I, Pozzi E, Luisetti M. Tumour necrosis factor family genes in a phenotype of COPD associated with emphysema. Eur Respir J 2003;21:444-449.

62. Agusti AG, Sauleda J, Miralles C, Gomez C, Togores B, Sala E, Batle $\mathrm{S}$, Busquets X. Skeletal muscle apoptosis and weight loss in chronic obstructive pulmonary disease. Am J Respir Crit Care Med 2002;166: 485-489.

63. Wouters EF, Creutzberg EC, Schols AM. Systemic effects in COPD. Chest 2002;121:127S-130S.

64. Rennard S. Energy expenditure in COPD, focus on basic mechanisms and interventions. Available from: www.medscape.com/internalmedi cinehome (accessed 2003).

65. Schols AM, Mostert R, Soeters PB, Wouters EF. Body composition and exercise performance in patients with chronic obstructive pulmonary disease. Thorax 1991;46:695-699.

66. Smith SC Jr, Blair SN, Bonow RO, Brass LM, Cerqueira MD, Dracup K, Fuster V, Gotto A, Grundy SM, Miller NH, et al. AHA/ACC scientific statement: AHA/ACC guidelines for preventing heart attack and death in patients with atherosclerotic cardiovascular disease: 2001 update: a statement for healthcare professionals from the American Heart Association and the American College of Cardiology. Circulation 2001;104:1577-1579.

67. Foglio K, Bianchi L, Bruletti G, Battista L, Pagani M, Ambrosino N.
Long-term effectivenss of pulmonary rehabilitation in patients with chronic airway obstruction. Eur Respir J 1999;13:125-132.

68. Finnerty JP, Keeping I, Bullough I, Jones J. The effectiveness of outpatient pulmonary rehabilitation in chronic lung disease: a randomized controlled trial. Chest 2001;119:1705-1710.

69. Casaburi R, Porszasz J, Burns MR, Carithers ER, Chang RS, Cooper CB. Physiologic benefits of exercise training in rehabilitation of patients with severe chronic obstructive pulmonary disease. Am J Respir Crit Care Med 1997:155:1541-1551.

70. O'Donnell DE, Lam M, Webb KA. Spirometric correlates of improvement in exercise performance after anticholinergic therapy in chronic obstructive pulmonary disease. Am J Respir Crit Care Med 1999;160: 542-549.

71. Newton MF, O'Donnell DE, Forkert L. Response of lung volumes to inhaled salbutamol in a large population of patients with severe hyperinflation. Chest 2002;121:1042-1050.

72. O'Donnell DE, Forkert L, Webb KA. Evaluation of bronchodilator responses in patients with "irreversible" emphysema. Eur Respir J 2001;18: 914-920.

73. Emtner M, Porszasz J, Burns M, Somfay A, Casaburi R. Benefits of supplemental oxygen in exercise training in nonhypoxemic chronic obstructive pulmonary disease patients. Am J Respir Crit Care Med 2003;168:1034-1042

74. Kasahara Y, Tuder RM, Taraseviciene-Stewart L, Le Cras TD, Abman S, Hirth PK, Waltenberger J, Voelkel NF. Inhibition of VEGF receptors causes lung cell apoptosis and emphysema. J Clin Invest 2000;106: $1311-1319$.

75. Kasahara Y, Tuder RM, Cool CD, Lynch DA, Flores SC, Voelkel NF. Endothelial cell death and decreased expression of vascular endothelial growth factor and vascular endothelial growth factor receptor 2 in emphysema. Am J Respir Crit Care Med 2001;163:737-744.

76. Sulkowska M, Sulkowski S, Terlikowski S, Nowak HF. Tumor necrosis factor-alpha induces emphysema-like pulmonary tissue rebuilding: changes in type II alveolar epithelial cells. Pol J Pathol 1997;48:179188.

77. Liao JK. Beyond lipid lowering: the role of statins in vascular protection. Int J Cardiol 2002;86:5-18.

78. Gotto AM Jr, Farmer JA. Pleiotropic effects of statins: do they matter? Curr Opin Lipidol 2001;12:391-394.

79. Rennard SI, Daughton DM. Cigarette smoking and disease. In: Elias JA, Fishman JA, Grippi MA, Kaiser LR, Senior RM, editors. Pulmonary diseases and disorders. New York: McGraw Hill; 1998. pp. 697-708. 